\title{
What the past suggests about future development of ecosystem service values applicable to USDA agricultural program evaluations
}

\author{
LeRoy T. Hansen $₫$
}

\begin{abstract}
Much of the research on ecosystem service values (ESVs) has limited applicability to USDA program benefit analyses, largely because the models/data/results (1) lack spatial breadth and hence cannot be applied in national analyses of USDA programs, and (2) do not link land use changes to the changes in ESs. This article provides an overview of a set of 15 ESVs related to agriculture's impacts on erosion in order to identify (1) weaknesses in methods, data, and assumptions that limit the quality of the ESVs and means of avoiding such weaknesses in future ESV development, and (2) approaches that might improve the reliability and spatial resolution of future ESV estimates.
\end{abstract}

Key words: ecosystem service values, environmental benefits, soil conservation benefits, USDA program benefits

\section{Introduction}

As of 2019, the United States Department of Agriculture (USDA) now spends over $\$ 5$ billion annually on conservation programs directed toward agricultural lands (USDA, ERS, 2019). Additionally, USDA's Conservation Compliance Program uses the funds that USDA pays to farm operators as "leverage" by requiring the adoption/use of particular conservation practices to remain eligible for program funds (Claassen et al. 2017). The main impact of these conservation programs is to modify farmland uses - such as by encouraging adoption of more benign production practices (working lands programs) or taking lands out of production (land retirement programs). Land-use change can affect multiple ecosystems and, hence, multiple ecosystem services (ESs). For example, a land-use change that improves wildlife habitat (perhaps by increasing the diversity of plant cover) can maintain or increase ecosystem services (such as wildlife viewing opportunities), or changes in land uses that improve water clarity can improve the quality of water-based recreational activities (such as fishing and swimming).

Measures of the value of these ecosystem services can provide insights about program accomplishments. Ecosystem service values (ESV) could also help

E-mail: leroy.t.hansen@gmail.com

Agricultural and Resource Economics Review 49/1 (April 2020) 7-22

(C) The Author(s) 2020. This is an Open Access article, distributed under the terms of the Creative

Commons Attribution licence (http://creativecommons.org/licenses/by/4.0/), which permits unrestricted re-use, distribution, and reproduction in any medium, provided the original work is 
program managers design programs to select practices and target locations where benefits are maximized relative to costs. For example, the USDA Conservation Reserve Program (CRP) contract selection process is based on an environmental benefit index (EBI). The index is a Farm Services Agency effort to capture the ecological scope of the CRP impacts (USDA, FSA, 2015). However, the EBI is largely based on biophysical measures that do not directly measure impacts on human welfare. Augmenting these biophysical indexes with accurate measures of ESVs, CRP contacts could be targeted to fields where societal benefits are maximized relative to costs.

While there is extensive research on ecosystem service values (ESVs), the methods and analyses described in that literature are often difficult or impractical to use to estimate ESVs provided by USDA's programs. For example, the retirement of farmland generates a myriad of ecosystem services that have non-point impacts. The myriad of small impacts diffused across a wide landscape often have individually small effects on the wellbeing of a large and diverse population. The sum of the many small values can be quite large relative to program costs. But as small impacts, they may be difficult to measure at an individual level.

To illustrate the prospects and challenges when generating USDA-relevant ESVs, this article provides an overview of a set of 15 ESVs that quantify some of the nonmarket benefits of erosion control. Though they consider only a small portion of USDA program benefits, they provide a means of identifying (1) methods, data, and assumptions that can support future research, (2) means of avoiding past weaknesses, and (3) methods that might improve development of ESVs. These ESVs are described in Box 1 and on the USDA Economic Research Service (ERS) website. ${ }^{1}$

\section{Models, Methods, Data, and Analyses}

\subsection{Linking changes in land use to changes in ecosystem services}

Analysts wishing to value USDA agricultural program impacts to ESs face challenges beyond the measurement of nonmarket values. Specifically, analysts must directly or indirectly link agriculture land-use changes to the subsequent changes in ecosystem services. Commonly, there are multiple biophysical links between a land-use change and its subsequent impacts on ESs (Figure 1). Figure 1 illustrates that more than one biophysical model may be needed to quantify effects of changes in land uses. For example, biophysical models can directly quantify effects-but are not sufficient to

\footnotetext{
1 This article does not provide an overview of the overall strengths and weaknesses of valuation methodologies or benefit transfer strategies. See Johnston in this journal, or Richardson et al. (2015), for a discussion of benefits transfer and valuation techniques.
} 
Box 1. Names and descriptions of the 15 USDA-relevant ecosystem service values (ESVs) discussed here.

\section{ESV name}

Reservoir services

Navigation

Water-based recreation

Marine fisheries

Freshwater fisheries

Marine recreational fishing

Municipal and industrial water use

Steam electric power plants

Irrigation ditches and canals

Flood damages

Irrigated agriculture

Soil productivity

Road drainage ditches

Municipal water treatment

Dust cleaning

\section{Definition of the ESVs}

The public's willingness to pay for less sediment and thus more services from reservoirs due to a reduction in soil erosion.

The navigation industry's willingness to pay to have less sediment affecting shipping channels and harbors.

People's willingness to pay to view and recreate in cleaner freshwater.

The marine fisheries industry's willingness to pay to reduce sediment's impact on fish catch.

The freshwater fisheries industry's willingness to pay to reduce sediment's impact on fish catch.

The public's willingness to pay for an improvement in fish catch-rates due to reductions in erosion.

Municipalities' and industries' willingness to pay to reduce damages caused by the salts and minerals in sediment.

Power producers' willingness to pay to reduce plant growth on heat exchangers caused by nutrients in suspended sediment.

Agriculture's willingness to pay to reduce the buildup of sediment and aquatic plants in irrigation ditches and canals.

The public's willingness to pay to reduce damages associated with flooding.

Farmers' willingness to pay to reduce the adverse yield impacts of the salts and minerals in irrigation waters that were dissolved from sediment.

Farmers' willingness to pay to reduce losses in soil productivity caused by erosion.

State governments' willingness to pay to have less sediment to remove from ditches along rural roads and highways.

Municipalities' willingness to pay to have less sediment in water processed for public consumption.

Households' willingness to pay to have less cleaning due to a reduction in wind erosion and wind-borne particulates. 


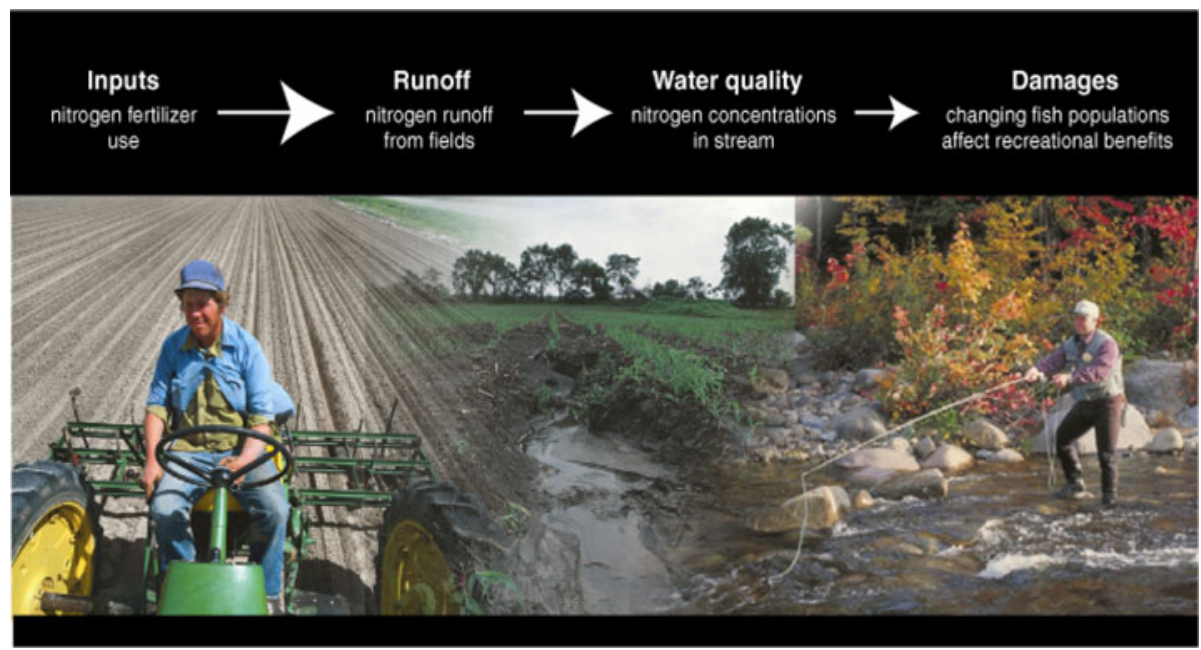

\section{Figure 1. An example of the links between agricultural land use and the value of impacts on ecosystem services}

Source: ERS analysis of Office of Budget and Policy Analysis data for 1996-2017 and Congressional Budget Office Estimates for 2018-2023.

model impacts on ESVs. In contrast, reduced-form models (discussed later) can indirectly measure effects but may have a narrow range of applicability.

To be useful in program analyses, the biophysical links must account for the spatial breadth of a USDA farm program's impacts, and the interconnectedness of many ecosystem services. For example, a change in the Conservation Reserve Program (CRP) will lead to changes in fields across the country. Similarly, a change in operator incentives in USDA working lands programs, such as those in the Environmental Quality Incentives Program (EQIP), will change the mix of conservation practices employed and can impact a wide scope of ESs (see: https://www.nrcs.usda.gov/wps/portal/nrcs/main/ national/programs/financial/eqip/).

The wide ecological scope of a conservation program reflects the fact that many ecosystems depend on similar environments. For example, a change in land use that affects water quality can affect all water-quality services-such as the health of fish populations or the degree of treatment necessary for use as drinking water. Additionally, such a land-use change can affect ecological services dependent on dryland habitat, such as bird, wildlife, and insect populations.

Finally, the benefits of a program change can only be evaluated if the biophysical links between program changes and ESs are quantified (illustrated in Figure 1). Several biophysical models are available but most evaluate a limited number of steps of the biophysical processes. Examples include the: 
1. Environmental Policy Integrated Climate (EPIC) model, which is a cropping systems model that estimates soil productivity impacts of changes in soil depth as affected by erosion (https://epicapex.tamu. edu/epic/),

2. Agricultural Policy/Environmental eXtender Model (APEX) model, which routes water, sediment, nutrients, and pesticides across complex, small watershed landscapes and channel systems to the watershed outlet and reservoirs (https://epicapex.tamu.edu/apex/),

3. Soil and Water Assessment Tool (SWAT), which is a river basin scale model that simulates the quality and quantity of surface and groundwater (https://swat.tamu.edu/), and

4. SPAtially Referenced Regressions on Watershed (SPARROW) model, which is a statistical/mechanistic hydrologic model that has been used in analyses of nutrient and sediment transport through large river systems (Schwarz et al. 2006; Alexander et al. 2008).

\subsection{Prioritizing ecosystem valuation research}

Setting priorities for future development of ESVs based on the expected sizes of the ESVs poses challenges. For example, to prioritize development of ESVs based on their expected sizes requires perspective on the size of the ESV and the size of agriculture's effect on the associated ES. We can gain some insights on setting research priorities by a rough comparison of the relative magnitudes of the 15 ESVs of Box 1. Dollar-per-ton values of each ESV are reported by 8-digit HUC (e.g., hydrologic unit code) watersheds in the contiguous United States (Hansen and Ribaudo 2008). ESVs are reported in over 1,500 HUCs (these are HUCs where agriculture uses a relatively large portion of the land). With so many HUCs, a HUC-by-HUC comparison would be a burden.

A simple way to compare magnitudes of the ESVs is to generate a national average value of each ESV. Values were calculated in two steps. First, the HUC-level values of each ES are summed across all HUCs (this is analogous to summing the values of a one-ton reduction in erosion in each HUC). And second, the total of each ESV is divided by the number of relevant HUCs (or, sticking with the analogy, each sum is divided by the total reduction in erosion), generating a national average of each ESV. ${ }^{2}$ To aid in making comparisons, the 15 national average ESVs are summed, generating a total national average ESV of $\$ 8.79$ (\$2017) - keep in mind that this value is

\footnotetext{
2 The calculation is based on the HUC-level ESV matrix reported in Hansen and Ribaudo (2008) where the column titles are the ESVs reported in Box 1 and the rows are the numeric values of the HUCs. A national average of each ESV is calculated by summing each column and dividing the column totals by the number of HUCs.
} 
meant to provide a perspective and is not meant to reflect a policy-relevant value.

A comparison of these national average values reveals that:

- While impacts on water-related ESs dominate, other impacts are worth considering. About 85 percent of the average value of a one-ton reduction in erosion is due to impacts on water-related ESs. The impacts on soil productivity $(\$ 0.79)$ and air quality/dust (\$0.55) are 9 percent and 6 percent, respectively, of the total average national ESV.

- 72 percent of the total water-quality ESVs is due to impacts on four of the 13 water-related ESs. Dominating all, at \$3.27 (44 percent of the water-quality impact and 38 percent of the total impact), is the value of impact on water-based recreation.

- A terse overview of research on the valuation of ESs suggests that more than half the analyses of water-quality benefits focus on recreation. The results presented here suggest a need for research on a broader set of ESs.

- Comparisons of regional average values do not reveal the same type of variations in ESVs. This is often because one or more of the ESs have zero values in a large portion of the HUCs (Hansen and Ribaudo 2008). For example, the dust-cleaning benefit is zero in all but the southwestern U.S. As a result, though small nationally, dust-cleaning cost is a considerably higher portion of the ESVs in the Southwest.

\subsection{Models and data use across analyses of the ESVS}

All ESV estimates are derived from on-field erosion levels calculated using one of two biophysical models: the Universal Soil Loss Equation (USLE) or, subsequently, the Revised Universal Soil Loss Equation (RUSLE) - which both generate sheet and rill erosion rates-and the Wind Erosion Equation (WEQ) and, subsequently, the Revised Wind Erosion Equation (RWEQ) - which both generate wind erosion rates. Model variables include land cover, soil type, topography, and expected weather patterns (USDA Agricultural Research Service 2016).

The conceptual frameworks applied in the studies that produced these ESV measures are the replacement cost approach, damage function approach, preventive expenditures, avoidance costs, revealed preference, and a partial equilibrium model of the agricultural sector.

All ESVs were estimated using the Natural Resource Inventory (NRI) data. The NRI data, maintained by USDA's Natural Resources Conservation Service (NRCS), is a periodic survey where a portion of its approximately 800,000 statistically based sample points on U.S. nonfederal range, crop, pasture, and forest lands are sampled every year (USDA Natural Resources Conservation 
Service 2018). The NRI includes all variables used in the RUSLE and RWEQ, including the cropping practices and tillage. Erosion levels resulting from a new policy can be calculated by applying the post-policy values of the cropping and tillage practice variables in RUSLE and RWEQ.

While the NRI has been essential in the development and application of ESVs, the level of statistical strength must be recognized in all applications. Specifically, it should be noted that the spatial sampling rates are only considered to be accurate at the sub-state level. All ESVs have been adjusted for price level changes based on the Consumer Price Index (CPI).

\subsection{Weaknesses and means of avoiding these in future ESV development}

This section discusses weaknesses in methods, data, and assumptions that limit the usefulness of the ESVs and offers means of avoiding these weaknesses in future development of ESVs. There are two overarching themes: (1) ESVs and ESV models should be readily available for policy analyses and easy to update, (2) biophysical models can offer the most substantial (or only) means of improving ESVs, and (3) updating data will always improve the reliability of an ESV.

We begin with four studies: two that report ESVs by HUC (Hansen and Hellerstein 2007; Feather, Hellerstein, and Tomasi 1995). The other two ESVs are reported by USDA, ERS Farm Production Region (FPR) but were originally generated on smaller geographic scales (Huszar and Piper 1986; Ribaudo 1989). The ERS (Economic Research Service) used Farm Production Regions to better align benefit estimates with program costs generated by an ERS partial equilibrium model of the U.S. agricultural sector.

Consider the first study (Feather, Hellerstein, and Tomasi 1995), which estimated ESVs using a Willingness to Pay (WTP) function for water-based recreation. The recreational behavioral and household characteristics variables were from the 1992 National Survey of Fishing, Hunting, and Wildlife Associated Recreation. The data included the Census track of the respondent, which was used to identify each respondent's HUC. The analysts used HUC-level estimates of erosion as a proxy for water quality. HUC-level erosion estimates were calculated using the USLE and the 1992 NRI. A baseline WTP was then calculated for each HUC by taking household characteristic variables from Census data and (what was then) the current values of all other independent variables.

Finally, the ESV was calculated for a target HUC using the same steps that generate the hypothetical baseline total WTP but with one critical difference: the erosion level in the target HUC was reduced by one ton (the marginal reduction). The marginal benefit of this erosion reduction was calculated using the difference between the baseline WTP value and this newly calculated WTP value. This calculation is done for each HUC having cropland erosion. The method generates the marginal cost of a one-ton reduction in a 
single HUC, all else being equal. The inflation-adjusted water-based recreation values are in Hansen and Ribaudo (2008).

This study shares with many other studies a number of simplifying assumptions and data quality issues. These include:

(1) Each water-based ESV is a marginal value. While such a value is appropriate in developing targeting programs, these values are not appropriate for valuing program changes because changes may not be marginal and are likely to occur at substitute sites. Future analyses can overcome this weakness by reporting the estimated functions and supporting data. The functions and data can be used to generate baseline (e.g., pre-policy) conditions and rerun using the post-policy variable values. The difference between the two is a measure of the welfare change.

(2) Marginal values are likely to change over time as conditions in local and substitute areas change. Here, again, we see the need for an updated value function-the updated function can generate time-relevant ESVs.

(3) The sizes of affected populations change over time. Updates are best when the sizes and demographics of populations are accounted for. Hence, when new Census data become available, WTP and ESVs can be updated.

(4) While reduced-form models are usually necessary, some consideration should be given to, and perhaps some estimation of, the implicit relationships in these models. For example, how has the increased acreage of buffer strips changed the relationship between erosion and water quality?

(5) The biophysical effects of erosion are likely to vary across water characteristics, such as water temperature and river-flow rates. Additionally, the water-quality effect of erosion will depend on the quantity of water that receives the agricultural effluences.

(6) The quality of waterbodies depends on erosion and on the volume of water that receives/holds the sediment. So, for example, the WTP function has erosion as an independent variable but should have also included a measure of water volume.

(7) HUC-level ESVs generated with the WTP function and NRI data may lack 
accuracy because the NRI cannot provide statistically reliable HUC-level erosion estimates. In future research, the accuracy of ESVs might be improved with better measures of independent variables, especially the HUC-level erosion rate.

Consider the study on reservoir services (Hansen and Hellerstein 2007). The economic framework defines reservoirs as assets that produce streams of ESs. Sediment diminishes the ES flows. Marginal decreases in erosion/ sedimentation marginally increases what would have been the future stream of ES flows. The value function was estimated using site-level dredging (e.g., restoration) cost, reservoir characteristics, and sedimentation. With growth in data availability, the increase in the number of observations can improve the rigor of the economic models.

The ESVs in Table 1 were developed from analyses that generated more spatially resolute estimates than FPRs. For example, the dust clean and road ditch models generated state-level estimates (Huszar and Piper, 1986). The municipal water treatment cost model generated estimates by Aggregated Sub Area (ASA) (e.g., for each of the 121 four-digit watersheds) in the U.S. (Holmes, 1988). Solley, Chase, and Mann (1983) used the results to produce state-level values.

Note that the dust cleaning, municipal water treatment, and road ditch maintenance ESVs are not marginal values and not average values-they have been referred to as "incremental values." They were calculated by estimating each economic model in two time periods. The value differences are divided by the erosion differences, thus generating an "incremental" value. The incremental ESVs are likely to be biased estimates of marginal and average values, though the direction of the bias is unknown.

The navigation ESVs are HUC-level estimates generated by calculating and summing per-ton costs. The analysts divide the dredging costs at each site by total upstream erosion (a dollar-per-ton of erosion estimate). The per-ton ESV for a HUC is the sum of the downstream site values. Despite the extensive cost data, no economic model was estimated-perhaps it was not possible.

The eight ESVs that have not been discussed also developed methods for distributing costs. All were estimated with limited data. Two in Table 1irrigated agriculture and irrigation ditch maintenance-were generated with state-level data. Six ESVs are based on a single economic value (Table 2). Each ESV was derived using somewhat similar methods. First, the national value is distributed across relevant ecosystems (i.e., estuaries) by dividing cost by the total number of ecosystems. Total FPR cost is the sum of the ecosystem values within a FPR. Total FPR cost is divided by the erosion within the FPR, thus generating a FPR's ESV.

The paucity of detailed data and the coarseness of biophysical models constrain the accuracy of these measures. Means and resources to collect such data might be limited. Improving biophysical models may be a relatively 


\section{Table 1. ESVs that are derived from estimated or previously estimated cost functions}

\begin{tabular}{|c|c|c|c|}
\hline ESV name & The economic values & Regional cost analysis & The ESV \\
\hline Dust cleaning & $\begin{array}{l}\text { A New Mexico survey of households } \\
\text { provided details on dust cleaning } \\
\text { efforts and other variables. The } \\
\text { NRI data and wind erosion } \\
\text { equation were used to generate } \\
\text { county-level erosion. }\end{array}$ & $\begin{array}{l}\text { WTP was estimated as a function of } \\
\text { county wind erosion and } \\
\text { respondent characteristic. Census } \\
\text { data and the WTP function were } \\
\text { used to generate estimates of the } \\
\text { population's WTP. }\end{array}$ & $\begin{array}{l}\text { Per-ton values were generated by } \\
\text { dividing the difference in cleaning } \\
\text { costs in } 1987 \text { and } 1982 \text { by the } \\
\text { difference in erosion. }\end{array}$ \\
\hline $\begin{array}{l}\text { Municipal } \\
\text { water } \\
\text { treatment }\end{array}$ & $\begin{array}{l}\text { Municipal data on per-gallon water } \\
\text { treatment cost, the volume of } \\
\text { water treated, and water turbidity. } \\
\text { Erosion levels were based on the } \\
\text { NRI and Universal Soil Loss } \\
\text { Equation. }\end{array}$ & $\begin{array}{l}\text { Per-gallon cost was estimated as a } \\
\text { function of turbidity. Turbidity is } \\
\text { estimated as a function of erosion. } \\
\text { Census data were then used to } \\
\text { generate regional water use and } \\
\text { costs. }\end{array}$ & $\begin{array}{l}\text { The ESV was based on erosion's effect } \\
\text { on turbidity and subsequent effect } \\
\text { on treatment costs. The models } \\
\text { were estimated with the } 1987 \text { and } \\
1992 \text { NRIs and Census data. } \\
\text { Differences in values are divided by } \\
\text { differences in erosion. }\end{array}$ \\
\hline $\begin{array}{l}\text { Road drainage } \\
\text { ditches }\end{array}$ & $\begin{array}{l}\text { State-level expenditures on removing } \\
\text { agricultural sediment from road } \\
\text { ditches. }\end{array}$ & $\begin{array}{l}\text { State-level cost was estimated as a } \\
\text { function of erosion, sediment } \\
\text { delivery, and road miles. }\end{array}$ & $\begin{array}{l}\text { For each region, the difference in costs } \\
\text { at two levels of erosion is divided } \\
\text { by the difference in erosion. }\end{array}$ \\
\hline $\begin{array}{l}\text { Irrigated } \\
\text { agriculture }\end{array}$ & $\begin{array}{l}\text { Per-acre value of yield losses due to } \\
\text { salts and minerals from } \\
\text { agricultural sediment came from a } \\
\text { study of the lower Colorado River } \\
\text { basin. }\end{array}$ & $\begin{array}{l}\text { Per-acre value are multiplied by a } \\
\text { region's irrigated acreage, } \\
\text { generating total erosion cost by } \\
\text { region. }\end{array}$ & $\begin{array}{l}\text { Regional totals are divided by total } \\
\text { agricultural erosion within the } \\
\text { region. }\end{array}$ \\
\hline $\begin{array}{l}\text { Irrigation } \\
\text { ditches and } \\
\text { canals }\end{array}$ & $\begin{array}{l}\text { Reported total state-level irrigation } \\
\text { ditch and canal maintenance costs. }\end{array}$ & $\begin{array}{l}\text { Agricultural erosion imposes } 25 \% \text { of } \\
\text { this cost is attributable to } \\
\text { agriculture. }\end{array}$ & $\begin{array}{l}\text { Regional totals are divided by total } \\
\text { agricultural erosion within the FPR. }\end{array}$ \\
\hline
\end{tabular}

Source: The ESV names and descriptions of the methods used are taken from Hansen and Ribaudo (2008). equation were used to generate NRI and Universal Soil Loss te-level expenditures on removing agricultural sediment from road Per-acre value of yield losses due to agricultural sediment came from a study of the lower Colorado River eported total state-level irrigation ditches and respondent characteristic. Census estimated as a function of erosion. generate regional water use and

tate-level cost was estimated as a function of erosion, sedimen

er-acre value are multiplied by a erosion cost by

Agricultural erosion imposes $25 \%$ of agriculture. 
Table 2. Six ESVs that are based on a national economic value

\begin{tabular}{|c|c|c|c|}
\hline ESV name & $\begin{array}{c}\text { The national } \\
\text { economic value }\end{array}$ & $\begin{array}{c}\text { Costs are distributed } \\
\text { across regions }\end{array}$ & The per-ton ESV \\
\hline $\begin{array}{l}\text { Marine } \\
\text { fisheries }\end{array}$ & $\begin{array}{l}\text { Value of reduction in } \\
\text { marine fish } \\
\text { harvests due to } \\
\text { agricultural } \\
\text { erosion. }\end{array}$ & $\begin{array}{l}\text { A per-estuary value was } \\
\text { calculated by dividing } \\
\text { the value by the } \\
\text { number of sediment- } \\
\text { impaired estuaries. }\end{array}$ & $\begin{array}{l}\text { The sum of the } \\
\text { within-region } \\
\text { estuary values } \\
\text { divided by total } \\
\text { water erosion } \\
\text { within the region. }\end{array}$ \\
\hline $\begin{array}{l}\text { Freshwater } \\
\text { fisheries }\end{array}$ & $\begin{array}{l}\text { Value of reductions } \\
\text { in Great Lakes' } \\
\text { fish harvests due } \\
\text { to agricultural } \\
\text { erosion. }\end{array}$ & $\begin{array}{l}\text { A per-estuary value was } \\
\text { calculated by dividing } \\
\text { the national value by } \\
\text { the number of Great } \\
\text { Lake estuaries with } \\
\text { ESs impaired by } \\
\text { sediment. }\end{array}$ & $\begin{array}{l}\text { The within-region } \\
\text { sum of the } \\
\text { estuaries values } \\
\text { divided by total } \\
\text { water erosion } \\
\text { within the region. }\end{array}$ \\
\hline $\begin{array}{l}\text { Marine } \\
\text { recreational } \\
\text { fishing }\end{array}$ & $\begin{array}{l}\text { Value of sediment's } \\
\text { degradation of } \\
\text { marine } \\
\text { recreational } \\
\text { fishing (function } \\
\text { of total days and } \\
\text { consumer surplus } \\
\text { per-day of } \\
\text { fishing). }\end{array}$ & $\begin{array}{l}\text { The value of marine } \\
\text { recreational impacts } \\
\text { divided by the } \\
\text { number of sediment- } \\
\text { impaired marine } \\
\text { estuaries. }\end{array}$ & $\begin{array}{l}\text { The sum of the } \\
\text { within-region } \\
\text { estuary values } \\
\text { divided by total } \\
\text { water erosion } \\
\text { within the region. }\end{array}$ \\
\hline $\begin{array}{l}\text { Municipal and } \\
\text { industrial } \\
\text { water use }\end{array}$ & $\begin{array}{l}\text { Damages to } \\
\text { household and } \\
\text { industrial water- } \\
\text { use equipment } \\
\text { due to salts and } \\
\text { minerals } \\
\text { associated with } \\
\text { soil erosion. }\end{array}$ & $\begin{array}{l}\text { Per-gallon damages are } \\
\text { calculated based on } \\
\text { total water } \\
\text { withdrawn by U.S. } \\
\text { households and } \\
\text { industries. }\end{array}$ & $\begin{array}{l}\text { Regional damages } \\
\text { are based on } \\
\text { regional water } \\
\text { withdrawals and } \\
\text { the per-gallon } \\
\text { cost. }\end{array}$ \\
\hline $\begin{array}{l}\text { Steam power } \\
\text { plants }\end{array}$ & $\begin{array}{l}\text { Cost of removing } \\
\text { aquatic plant } \\
\text { growth } \\
\text { attributable to } \\
\text { nutrients attached } \\
\text { to sediment, from } \\
\text { cooling systems. }\end{array}$ & $\begin{array}{l}\text { Per-gallon costs are } \\
\text { equated to total cost } \\
\text { divided by total water } \\
\text { withdrawn for } \\
\text { thermoelectric power } \\
\text { generation. }\end{array}$ & $\begin{array}{l}\text { Regional costs are } \\
\text { based on total } \\
\text { regional } \\
\text { withdrawals and } \\
\text { per-gallon cost. }\end{array}$ \\
\hline $\begin{array}{l}\text { Flood } \\
\text { damages }\end{array}$ & $\begin{array}{l}\text { Total damages from } \\
\text { flooding due to } \\
\text { agricultural } \\
\text { sediment. }\end{array}$ & $\begin{array}{l}\text { Percent of flood damage, } \\
\text { by regions, reported } \\
\text { by the U.S. Water } \\
\text { Resources Council. }\end{array}$ & $\begin{array}{l}\text { Regional damage is } \\
\text { the percent of } \\
\text { total damages } \\
\text { times the total } \\
\text { damage estimate. }\end{array}$ \\
\hline
\end{tabular}

Source: The ESV names and descriptions of the methods used are taken from Hansen and Ribaudo (2008). 
easy and straightforward means of improving these and similar types of analyses, largely because improvements in hydrologic models can be used to improve the derivation of multiple types of ESVs. For example, a hydrologic model that accurately tracks changes in on-field erosion to the impacts on estuaries might be used to value harbor dredging costs and the recreational impacts of changes in sediment-impaired estuaries.

Future derivations of ESVs will need the same (or similar to the) two-step process: distribute a national value to regions and generate the ESVs from the regional values. For example, Moore et al. (2017) derived estimates of household and total willingness to pay for changes in water clarity and number of bass, crab, and oysters in the Chesapeake Bay, based on models of reductions in sediment, nutrients, and phosphorus. The models did not differentiate effects based on where pollutants entered the Bay-e.g., pollutants in the northern edge are assumed to have the same impact as pollutants on the southern edge. Hence, in order to apply the values and models to the watersheds that feed into the Bay, analysts must first differentiate effects based on inflow locations/estuaries and second, calculate the ESVs based on the estuary values. Another example of a single-location impact is the Gulf of Mexico hypoxic zone-it is, essentially, a single site that is affected by nutrients leaving fields throughout the greater Mississippi River Basin.

The available ESVs provide a perspective of the importance of spatial resolution of ESVs and value functions. Three studies generating HUC-level ESVs (Hansen and Hellerstein 2007; Hansen et al. 2002; and Feather, Hellerstein, and Tomasi 1995). Summing by HUC, ESVs are shown to range from zero to over $\$ 16$ per ton and vary widely across the country (Figure 2). Though each FPR includes several states, the regional total ESVs show a nearly threefold variation in values, ranging from $\$ 3.01$ to $\$ 10.12$ (Figure 3).

\subsection{Approaches that might improve the development of ESVS}

Robust and accurate findings are best achieved by models and methods that capture differences in ecosystems and the mix of ESs produced. For example, valuation of the wildlife-related ESs produced by the Conservation Reserve Program (CRP) must recognize that species' habitats often exclude areas with different climates. Completeness matters in capturing the spectrum of ecosystem service benefits. For example, the water-based recreation model might have been improved (as well as the ESVs) had the analysts included agriculture's loading of nitrogen, phosphorus, and other determinants of water quality. Changes over time are likely-it is important not only to update values of independent variables of WTP and cost functions but also to consider other variables. For example, if a population doubled, would crowding begin to lower WTP? This question might be answered using multisite analyses rather than a national survey. 


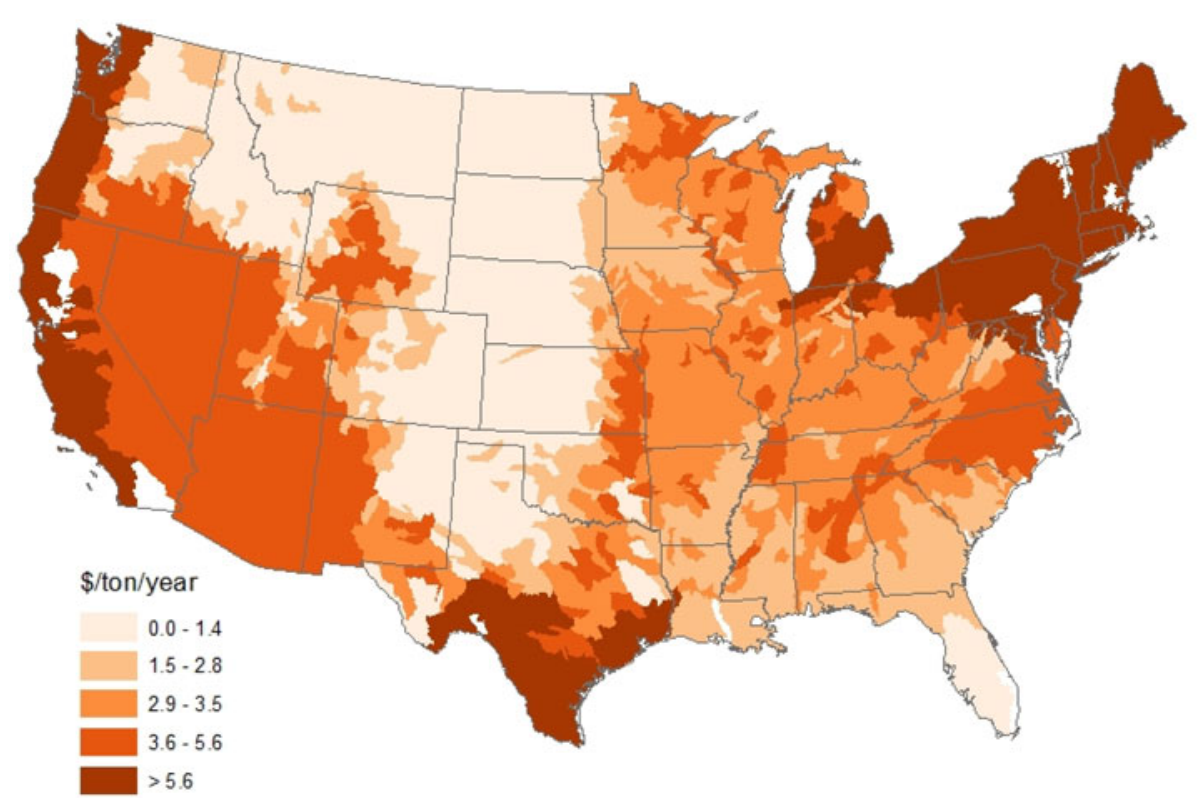

Figure 2. ESVs are approximately zero in 251 , are less than $\$ 3.50$ in more than half of the 2,111 HUCs, and reach a peak of $\$ 16.40$ per ton.

Source: Based on data reported in Hansen and Ribaudo (2008)

What will be useful for decision makers when data are too limited to allow definitive estimation of a cost or benefit functions. One goal is to provide insight on the shape of the value functions, especially in cases where a limited number of people make decisions. For example, nearly all dredging of shipping channels is done be the U.S. Army Corps of Engineers (USACE). So it would be helpful to provide information to decision makers to consider questions like, "Does the USACE dredge less often when there is less sediment (e.g., are all costs reduced?) or is the dredging schedule constant?"

\section{Summary}

This research identified methods, data, and assumptions that were used to develop a set of 15 ESVs designed to evaluate changes in ESs that may be affected by USDA conservation programs. By providing an overview of the research behind the ESVs, and looking for ideas that will aid future development of USDA-relevant ESVs, we hope to encourage the professional community to explore and think creatively on advancing the science of developing USDA-relevant ESVs. 


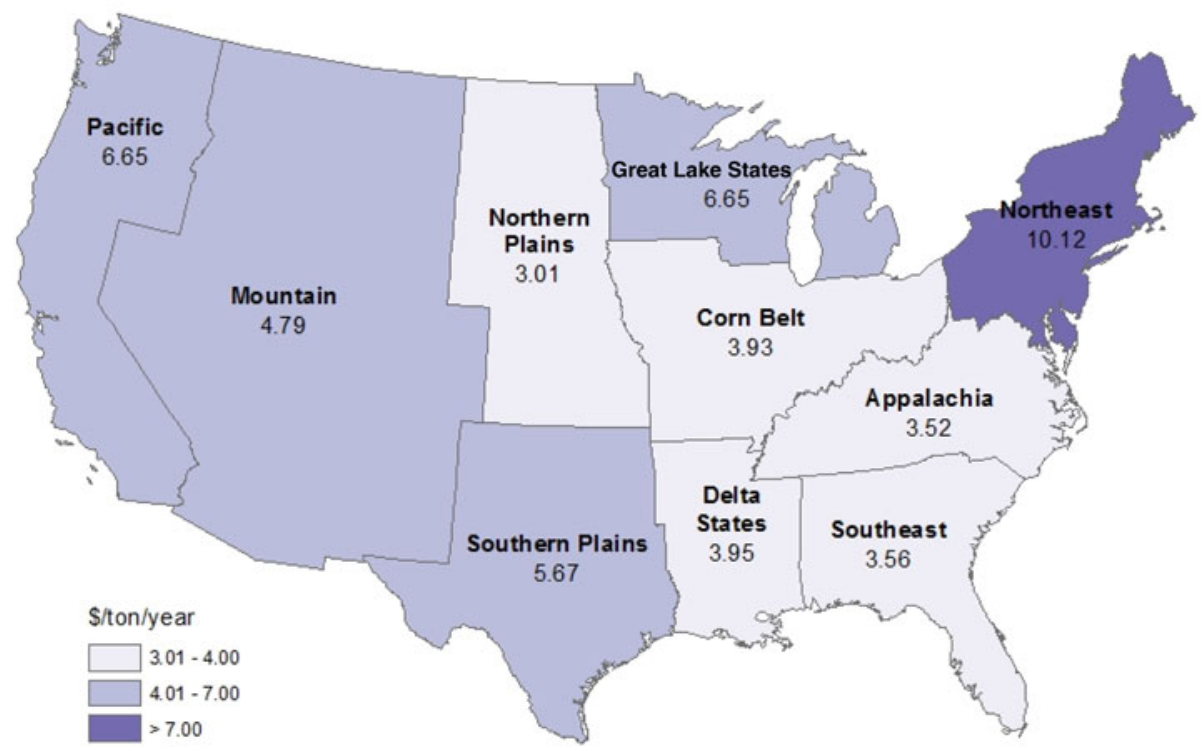

Figure 3. The sum of the 12 Farm Production Region-level ESV estimates of a change in soil erosion range from $\$ \mathbf{3 . 0 0}$ to over $\mathbf{\$ 1 0 . 0 0}$.

Source: Based on data reported in Hansen and Ribaudo (2008)

While the valuation of nonmarket benefits poses many challenges, analysts wishing to develop USDA-relevant ESVs and value functions must also realize the spatial breadth of programs' impacts and the need to quantitatively link program changes to changes in ESs. The ESVs reviewed here have spatial breadth and embody the biophysical relationships between land-use changes and ESVs, but all have weaknesses. A comparison of the magnitudes of these ESVs shows that while water-based recreational values are relatively high, they are less than half of the total benefits of erosion reductions that have so far been estimated. This suggests the usefulness of research on other benefits. The comparison of the ESVs also shows large spatial variations in ESVs, hence a need for spatially resolute ESVs and value functions.

Weaknesses in the existing ESVs discussed would often be overcome if the estimated models and supporting data were available. In two cases, the reported ESVs are marginal value estimates, which can support targeting decisions. But they are not appropriate for program evaluation. This weakness can be avoided if the value function and data were available. The function generates estimates of program changes by finding the difference between the value function with and without the change. The value function also can be used to update the ESVs (e.g., the marginal values).

Weaknesses also stem from a lack of reliable biophysical models. While economists can generate reliable ESVs, such values cannot be applied to 
USDA program analyses unless the effects of changes in land uses can be linked to the ESs.

Another weakness is that many ESVs are average-value estimates. Average values were developed in situations where value functions could not be empirically estimated. In some cases, there are a limited number of decisions made, so few observations are available. In the future, analysts who wish to gain insights on the shape of the value functions might interview the decision makers. Results are likely to be better than the past average value estimates.

Some of these ESVs were derived from a single national economic value. The two-step method used to create the ESVs will be necessary in the future in situations where agriculture practices across a large region affect ecosystems in a single location, such as an evaluation of agriculture's impact on the hypoxia zone in the Gulf of Mexico. A full evaluation of a program change requires estimates of all ESVs-including those where agriculture has little or no effect. Identifying zero-value estimates ensures the public, program operators, and policy makers that all ESs have been considered.

\section{Acknowledgments}

The author would like to thank the anonymous reviewers for helpful suggestions, and also Daniel Hellerstein for insightful comments and for assuming a major role in addressing technical and editorial comments. The author assumes responsibility for any errors in the paper and supporting analysis.

\section{References}

Alexander, R.B., R.A. Smith, G.E. Schwarz, E.W. Boyer, J.V. Nolan, and J.W. Brakebill, 2008. "Differences in Phosphorus and Nitrogen Delivery to the Gulf of Mexico From the Mississippi River Basin." Environmental Science and Technology 42:822-830. Available at https://pubs.acs.org/doi/abs/10.1021/es0716103.

Claassen, R., M. Bowman, V. Breneman, T. Wade, R. Williams, J. Fooks, L. Hansen, R. Iovanna, and C. Loesch. 2017. "Conservation Compliance: How Farmer Incentives Are Changing in the Crop Insurance Era." Economic Research Report 234 (ERR-234) 63 pp, July https:// www.ers.usda.gov/publications/pub-details/?pubid=84456.

Feather, P.., D. Hellerstein, and T. Tomasi. 1995. "A Discrete-Count Data Model of Recreation Demand." Journal of Environmental Economics and Management. Vol. 29. Available at https://www.researchgate.net/publication/223052413_A_Discrete-Count_Model_ of_Recreation_Demand.

Hansen, L., V. Breneman, C. Davison, and C. Dicken. 2002. The Cost of Soil Erosion to Downstream Navigation. Journal of Soil and Water Conservation 57(4):205 212. July/ August. Available at https://www.researchgate.net/publication/43289780_The_Cost_ of_Soil_Erosion_to_Downstream_Navigation.

Hansen, L., and D. Hellerstein. 2007. "The Value of the Reservoir Services Gained with Soil Conservation." Land Economics 83(3):285 301. Available at http://le.uwpress.org/ content/83/3/285.full.pdf+html.

Hansen, L., and M. Ribaudo. 2008. "Economic Measures of Soil Conservation Benefits: Regional Values for Policy Assessment. Technical Bulletin (TB 1922)." U.S. Department 
of Agriculture, Economic Research Service. 31 pp. September. Available at https://www. ers.usda.gov/publications/pub-details/?pubid=47550.

Holmes, T.P. 1988. "Soil Erosion and Water Treatment." Land Economics 64, pp. 356-366.

Huszar, P.C., and S.L. Piper. 1986. "Estimating the Offsite Costs of Wind Erosion in New Mexico." Journal of Soil and Water Conservation 42, 6. Pp. 414-16.

Moore, C., D. Guignet, D. Guignet, C. Dockins, and N. Simon. 2017. "Valuing Ecological Improvements in the Chesapeake Bay and the Importance of Ancillary Benefits." Journal of Benefit-Cost Analysis 9(01):1-26. June. DOI: 10.1017/bca.2017.9 Available at https://www.researchgate.net/publication/317604367_Valuing_Ecological_Improvements_ in_the_Chesapeake_Bay_and_the_Importance_of_Ancillary_Benefits.

Ribaudo, M. 1989. "Water Quality Benefits from the Conservation Reserve Program." U.S. Department of Agriculture, Economic Research Service. AER-606. February.

Richardson, L., J. Loomis, T. Kroger, and F. Casey (2015). "The Role of Benefit Transfer in Ecosystem Service Valuation." Ecological Economics 115, 51-58.

Schwarz, G.E., A.B. Hoos, R.D. Alexander, and R.A. Smith. 2006. "The SPARROW Surface WaterQuality Model - Theory, Applications and User Documentation." U.S. Geological Survey: Reston, Virginia. Available at https://aslopubs.onlinelibrary.wiley.com/doi/10.4319/lo. 2006.51.1_part_2.0356.

Solley, W.B., E.B. Chase, and W.B. Mann, IV. 1983. "Estimated Use of Water in the United States in 1980." Geological Survey Circular. 1001. U.S. Geological Survey.

U.S. Department of Agriculture, Agricultural Research Service, 2016, Revised Universal Soil Loss Equation (RUSLE) - Welcome to RUSLE 1 and RUSLE 2." Watershed Physical Processes Research: Oxford, MS. October 2016. Available at https://www.ars.usda. gov/southeast-area/oxford-ms/national-sedimentation-laboratory/watershed-physicalprocesses-research/docs/revised-universal-soil-loss-equation-rusle-welcome-to-rusle1-and-rusle-2.

U.S. Department of Agriculture, Economic Research Service, 2019, "Conservation" in Agriculture Improvement Act of 2018: Highlights and Implications, February. Available at https://www.ers.usda.gov/agriculture-improvement-act-of-2018-highlightsand-implications/conservation/.

U.S. Department of Agriculture, Farm Services Agency. 2015. "Conservation Fact Sheet: Conservation Reserve Program 49th General Enrollment Period Environmental Benefits Index (EBI)." December. Available at https://www.fsa.usda.gov/Assets/USDAFSA-Public/usdafiles/FactSheets/archived-fact-sheets/crp_49th_GEP_EBI.pdf.

U.S. Department of Agriculture, Natural Resources Conservation Service, 2018, "National Resources Inventory: A statistical survey of land use and natural resource conditions and trends on U.S. non-Federal lands." NRCA Natural Resources Assessment. Available at https://www.nrcs.usda.gov/wps/portal/nrcs/main/national/technical/nra/nri/. 